\title{
Arctic fox dispersal from Svalbard to Canada: one female's long run across sea ice
}

\author{
Eva Fuglei ${ }^{1} \&$ Arnaud Tarroux ${ }^{2}$ \\ ${ }^{1}$ Norwegian Polar Institute, Fram Centre, Tromsø, Norway; \\ ${ }^{2}$ Department of Arctic Ecology, Norwegian Institute for Nature Research, Fram Centre, Tromsø, Norway
}

\begin{abstract}
We report the first satellite tracking of natal dispersal by an Arctic fox (Vulpes lagopus) between continents and High-Arctic ecosystems. A young female left Spitsbergen (Svalbard Archipelago, Norway) on 26 March 2018 and reached Ellesmere Island, Nunavut, Canada, 76 days later, after travelling a cumulative distance of $3506 \mathrm{~km}$, bringing her ca. $1789 \mathrm{~km}$ away (straight-line distance) from her natal area. The total cumulative distance travelled during the entire tracking period, starting when she left her natal area on 1 March 2018 and ending when she settled on Ellesmere Island on 1 July 2018 , was $4415 \mathrm{~km}$. This is among the longest dispersal events ever recorded for an Arctic fox. Crossing extensive stretches of sea ice and glaciers, the female moved at an average rate of $46.3 \mathrm{~km} /$ day $\pm 41.1 \mathrm{SD}$. The maximum movement rate was $155 \mathrm{~km} /$ day and occurred on the ice sheet in northern Greenland. This is the fastest movement rate recorded for this species. The northernmost location recorded was on the sea ice off northern Greenland at a latitude of $84.7^{\circ} \mathrm{N}$. The Arctic fox was of the blue colour morph typical for coastal environments, where Arctic foxes are adapted to food webs without lemmings but with substantial inputs of marine food resources. The Arctic fox settled on Ellesmere Island in a food web with lemmings, thereby switching ecosystems. Our observation supports evidence of gene flow across Arctic regions, including those seasonally bridged by sea ice, found in studies of the circumpolar genetic structure of Arctic fox populations.
\end{abstract}

\section{Keywords}

Argos satellite tracking; blue morph; coastal fox; lemming fox; large-scale movements; vulpes lagopus

\section{Correspondence}

Eva Fuglei, Norwegian Polar Institute, Fram Centre, PO Box 6606 Langnes, NO-9296 Tromsø, Norway. E-mail: eva.fuglei@npolar.no

\section{Abbreviations}

AMSR2: Advanced Microwave Scanning Radiometer 2; SD: standard deviation

\section{Introduction}

On the sea ice on 26 April 1885 at $85^{\circ} \mathrm{N}$, during his expedition to the North Pole, the explorer Fridtjof Nansen noted: "I was not a little surprised yesterday morning when I suddenly saw the track of an animal in the snow. It was that of an Arctic fox [...]. The trail was quite fresh. What in the world was that fox doing up here out on the wild sea?" (Nansen 1897: 294). The Arctic fox (Vulpes lagopus) has become known for its exceptional mobility and endurance in barren polar environments (Chesemore 1968; Wrigley \& Hatch 1976; Eberhardt \& Hanson 1978; Eberhardt et al. 1983) and tentative answers to Nansen's question have been offered by several generations of Arctic fox researchers. Arctic fox excursions on sea ice were early on explained as seasonal foraging trips (Chesemore 1968; Garrott \& Eberhardt 1987). Such behaviour could be sparked by polar bears (Ursus maritimus) making carrion available on sea ice (Smith 1980;
Lydersen \& Gjertz 1986), or seasonal or annual scarcity of key terrestrial resources such as migrating birds, lemmings or carcasses of larger mammals (Braestrup 1941; Wrigley \& Hatch 1976). However, ear-tagged Arctic foxes have provided evidence for movements over sea ice exceeding 1000 km (Chesemore 1968; Wrigley \& Hatch 1976; Eberhardt \& Hanson 1978; Eberhardt et al. 1983), beyond what could be expected from occasional foraging trips from breeding home ranges.

In the last 20 years, satellite telemetry in North America has revealed heretofore uknown details of the spatial ecology of Arctic foxes (Follmann \& Martin 2000; Pamperin et al. 2008; Tarroux et al. 2010; Lai et al. 2015; Rioux et al. 2017). Such studies have demonstrated the extensive use of sea ice as a foraging habitat and as a platform for exploration and dispersal. Understanding what triggers movements of animals from the birth place to a potential breeding place (natal dispersal), or from one breeding place to another (breeding dispersal), is important for 
the study of population dynamics and the distribution of species (Clobert et al. 2001). There is a large literature on what drives dispersal in animals. Profound spatial and temporal variability in population density and resource abundance are considered to be particularly forceful drivers of dispersal (Ims \& Hjermann 2001).

The Arctic fox is generally classified into two ecotypes: "coastal fox" and "lemming fox" (Braestrup 1941). The coastal ecotype lives on Arctic islands without lemmings (Lemmus and Dicrostonyx spp.) and largely relies on food sources from the marine food web (Prestrud 1992; Hersteinsson \& Macdonald 1996; Ehrich et al. 2015). The coastal ecotype is most typically represented by a dark ("blue") colour morph, reflecting that the foxes are often moving against a dark ground in regions with ice- and snow-free coastlines in winter (Fuglei \& Ims 2008). The lemming ecotype (predominantly of the white colour morph) is heavily dependent on cyclic peaks of lemming populastions for successful breeding, but may shift to other terrestrial or marine resources in years of low lemming abundance (Bêty et al. 2002; Roth 2002; Angerbjörn et al. 2004; Ehrich et al. 2015). It has been suggested that long-distance movements and nomadic behaviour are more common in the lemming ecotype than in the coastal ecotype (Braestrup 1941; Pullainen 1965; Wrigley \& Hatch 1976; Pamperin et al. 2008; Tarroux et al. 2010; Norén et al. 201 1; Lai et al. 2017). The low food availability and higher fox population densities after a lemming peak may generate high levels of intraspecific competition, triggering dispersal (Roth 2002; Lai et al. 2015). The few published records of Arctic fox movements based on satellite telemetry stem from ecosystems with lemmings in North America (Pamperin et al. 2008; Tarroux et al. 2010; Lehner 2012; Lai et al. 2017).

Centrally located in the Polar Basin, the Norwegian archipelago of Svalbard is seasonally linked to Greenland and North America by sea ice that offers a potential means for long-distance dispersal for the islands' Arctic foxes. However, evidence for such movements has been only indirect up to now, in the form of genetic analyses. Here we report on a young female Arctic fox-part of a larger and ongoing study of Arctic fox spatial ecology in Svalbard-that travelled from Svalbard to Ellesmere Island, Nunavut, Canada, during a few months in spring 2018.

\section{Methods}

\section{Study area}

The Arctic fox reported on here was part of a study $(n=54)$ that started in 2012 on the west coast of Spitsbergen, the largest island in the High-Arctic Svalbard Archipelago $\left(74^{\circ}-81^{\circ} \mathrm{N}, 10^{\circ}-30^{\circ} \mathrm{E}\right)$. A female Arctic fox of the blue colour morph was captured on 29 July 2017, probably close to her natal den near the front of the glacier Fjortende Julibreen $\left(79^{\circ} 06^{\prime} \mathrm{N}\right.$ and $\left.11^{\circ} 52^{\prime} \mathrm{E}\right)$, in Krossfjorden. We used two trapping methods in the study: a Swiss-snare system consisting of a spring-mounted plastic-coated foot snare (Nybakk et al. 1996; Eide et al. 2004) mounted on a modified padded leg-hold trap system (Victor No. 1 SoftCatch ${ }^{\circledR}$ padded leg-hold trap); and a Tomahawk Live Trap $(100 \times 30 \times 30 \mathrm{~cm})$. The fox discussed in this paper was caught in a cage trap. During the study, traps were continuously observed from a distance of 250 to $400 \mathrm{~m}$ through a telescope or binoculars, and when the female fox was trapped she was removed from the trap within five minutes. The fox was sexed, weighed (1900 g) and her age class estimated on the basis of her tooth wear (juvenile). She was then outfitted with a 115-g KiwiSat 303 Argos platform transmitter (CLS 2016; Biotrack Ltd.)

\section{Satellite tracking, data filtering and processing environmental data}

The satellite collar transmitted daily for a three-hour period between 14:00 and 17:00 GMT with a repetition rate of 60 seconds.

We removed positions for which the location processed had failed (location class "Z"; CLS 2011) before applying a Bayesian state-space model (Jonsen et al. 2005; Jonsen 2016) to filter the data and obtain a single position per day. Filtering was done with the fit_ssm function from the bsam package (Jonsen et al. 2005; Jonsen 2016), using a first-difference correlated random walk with burn-in $=50000$ and sample size $=500$ 000, thinned by 100. Daily gridded AMSR2 sea-ice data resampled at a resolution of $3.25 \mathrm{~km}$ (Spreen et al. 2008) were retrieved from the University of Bremen's Sea Ice Remote Sensing website (https://seaice. uni-bremen.de/start/data-archive/). Topographic data were extracted from the General Bathymetric Chart of the Oceans (GEBCO 2019). Data processing, analysis and mapping were performed in R.3.5.1 (R Development Core Team 2018). Data were projected in polar stereographic projection with $75^{\circ} \mathrm{N}$ as standard parallel and $0^{\circ}$ as central meridian, using functions available from $s p$ and raster packages (Bivand et al. 2008; Hijmans 2018). Average daily movement rates ( $\mathrm{km} /$ day) were calculated assuming linear movements between successive locations and therefore correspond to minimum distances covered daily.

\section{Results and discussion}

The tracking period presented here lasted exactly four months, that is, from 1 March 2018 to 1 July 2018. 
During that entire period, the young female Arctic fox covered a total cumulative distance of $4415 \mathrm{~km}$, representing a straight-line distance of $1789 \mathrm{~km}$ between her natal area and her position on 1 July 2018 (Fig. 1; see also the supplementary animation). The short span of time spent covering such a distance highlights the exceptional movement capacity of this small-sized carnivore species. This journey was inter-continental in that the fox travelled from Svalbard, in Europe, to Ellesmere Island, in North America. A similar travelling distance was reported for an adult female Arctic fox within the Canadian Arctic that travelled $4599 \mathrm{~km}$, but over a longer period of 5.5 months (Tarroux et al. 2010). Like the Canadian case, the Svalbard fox used sea ice extensively to bridge distant regions (Pamperin et al. 2008; Tarroux et al. 2010; Lehner 2012).
From the date the Svalbard fox was outfitted with a satellite transmitter, on 29 July 2017, and until approximately l March 2018, she stayed in a ca. $30 \times 80 \mathrm{~km}$ area along the coastline of western Spitsbergen (Fuglei $\delta$ Tarroux, unpubl. data). She first moved to the northeast of Spitsbergen and reached the ice-free shore on 11 March 2018 (Fig. 1; supplementary animation). She then changed course and headed west, reaching the shore, where she again met open water on 16 March 2018 (Fig. 1; supplementary animation). There the Arctic fox turned again, heading south-east and crossing the northern part of Spitsbergen from west to east, where, on 26 March 2018, she met ice-covered sea for the first time and left Spitsbergen (Figs. 1, 2), heading north-east on the sea ice. One day later, her route turned northward and then westward, towards north Greenland, which

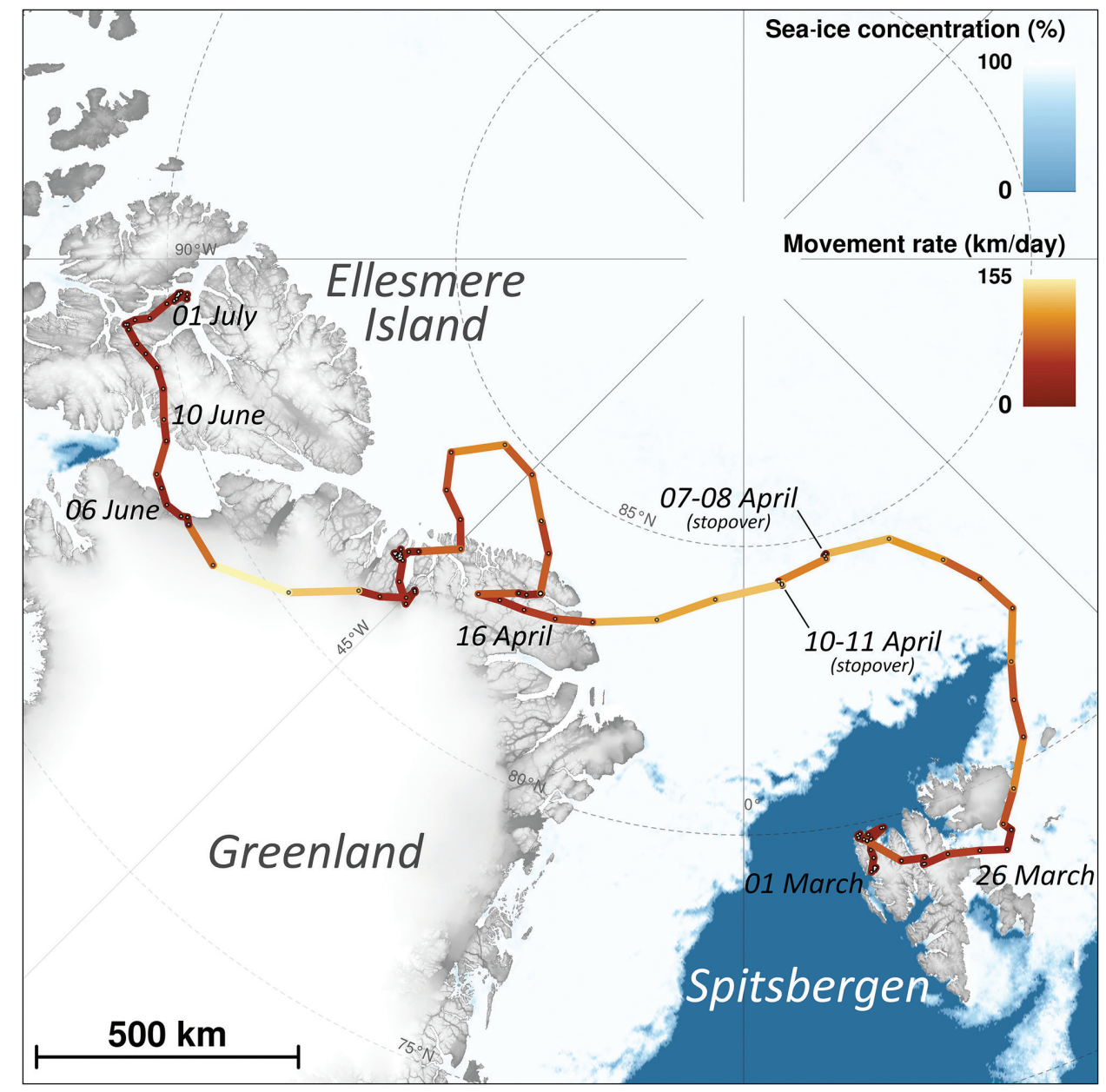

Fig. 1 Large-scale movements of a young female Arctic fox from Svalbard tracked through Argos satellite telemetry from 1 March to 1 July 2018 (date of passage is indicated at several locations along the track). The black dots represent the daily locations, and the colour of the segments linking successive locations indicates the daily movement rate. The sea-ice data show the concentration on 2 April 2018. Sea-ice data retrieved from https://seaice. uni-bremen.de/data/ (Spreen et al. 2008). Map projection is Polar Stereographic (EPSG3996). For an animated version of this map, see the supplementary animation. 


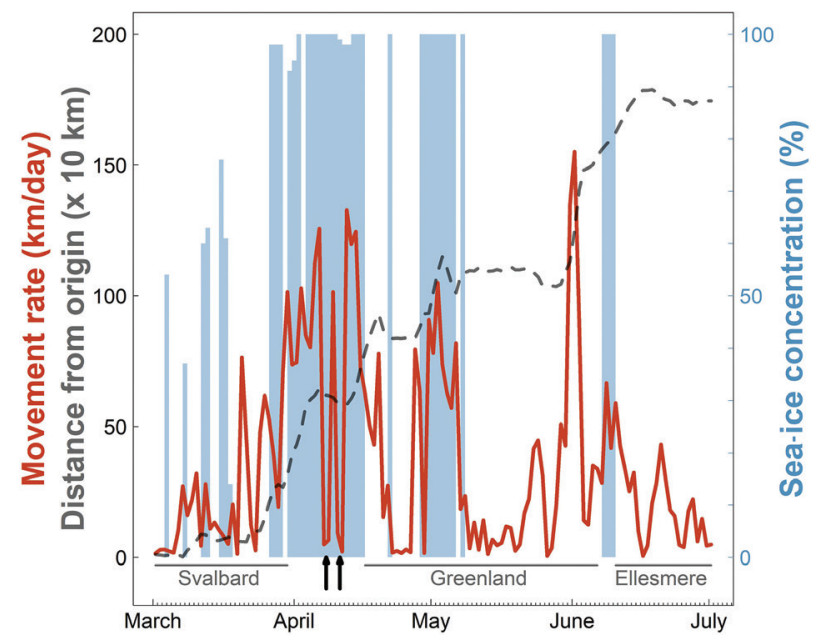

Fig. 2 Daily movement rates (red line) and straight-line distance from the point of departure (distance from origin; grey dashed line) at each location along the path of a young female Arctic fox. The blue shaded bars indicate the sea-ice concentration when the fox was travelling on sea ice. The two black arrows indicate two short stopovers (7-8 and 10-11 April) on the sea ice between Svalbard and Greenland (Fig. 1).

she reached 21 days (16 April 2018) and $1512 \mathrm{~km}$ after having left Spitsbergen. She finally reached Ellesmere Island, Nunavut, Canada, 76 days (10 June 2018) after leaving Spitsbergen. Here she stayed in a limited area around the Fosheim Peninsula, until the satellite transmitter stopped transmitting on 6 February 2019 (Fuglei $\delta$ Tarroux, unpubl. data). As the journey documented here transferred the young female fox from a natal home range (in Spitsbergen) to a new terrestrial home range (on Ellesmere Island), it fits the definition of natal dispersal (Clobert et al. 2001).

The fox's average movement rate varied greatly throughout the journey from Spitsbergen to Ellesmere, with a mean of $46.3 \mathrm{~km} /$ day ( $\pm 41.1 \mathrm{SD}$; Table 1, Fig. 3) and peaking at $155 \mathrm{~km} /$ day (Fig. 2). This is, to our knowledge, the fastest movement rate ever recorded for this species, 1.4 times faster than the maximum rate recorded in the previously reported long-distance movement of an adult male Arctic fox in Alaska (113 km/day; Lehner 2012). The female travelled most quickly while crossing the ice sheet in north-western Greenland (Fig. 1). Her average movement rate was higher by $34.0 \mathrm{~km} /$ day $(95 \% \mathrm{CI}=$ [16.5; 51.5]) when travelling on sea ice than when travelling on land (Fig. 3), suggesting that sea ice was used predominantly as a platform for dispersal, rather than as a foraging habitat. Although Fig. 3 does not discriminate between tundra and glacier (i.e., both are considered land), Fig. 1 shows that the Arctic fox also travelled rapidly when moving over the Greenland ice sheet, a habitat that cannot offer many foraging opportunities.
Table 1 Summary of the movement parameters of a young satellite-tracked female Arctic fox dispersing from Svalbard, Norway, to Ellesmere Island, Nunavut, Canada.

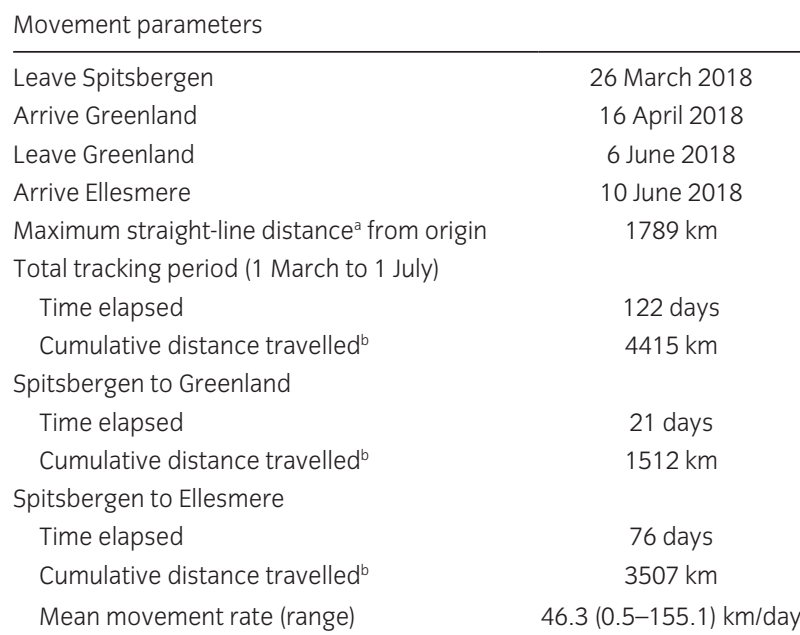

aStraight-line distance means the distance "as the crow flies" between two geographical points. 'Distance travelled means the cumulated distance over successive locations along the path.

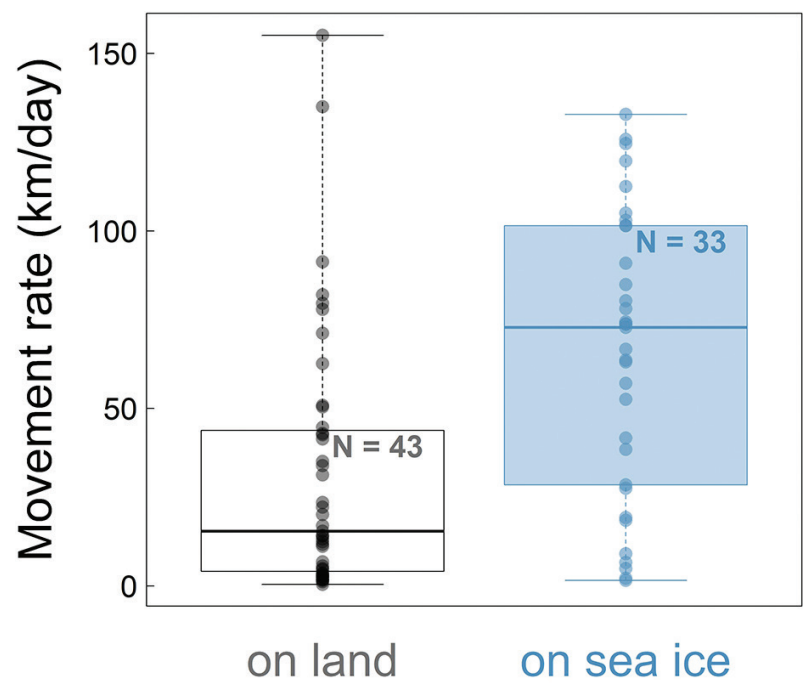

Fig. 3 Boxplot of the daily movement rates of a young female Arctic fox when on land and on sea ice. The horizontal bars represent the median, the boxes show the interquartile (25-75\% percentiles) and the whiskers show the whole range. Only locations during the journey from Spitsbergen to Ellesmere Island ( $n=76$ ), between 26 March and 10 June 2018, are considered here.

Despite a high average movement rate on the sea ice, the movement rate dropped below $10 \mathrm{~km} /$ day for 48 hours on two occasions (7-8 April and 10-11 April; Figs. 1, 2). Such short stopovers might indicate physical barriers on the sea ice, bad weather or the occurrence of a food source; observing fox tracks by ice leads, Nansen 
(1897) speculated that the animals could snap up crustaceans from the open water. The sea ice at the location where the fox had the two stopovers is dynamic, with frequent lead formations that are characteristic for the pack ice north of Svalbard (Assmy et al. 2017). The leads act as biological hot spots attractive to amphipods, seabirds and marine mammals (Assmy et al. 2017), such as ringed seal (Pusa hispida), hooded seals (Cystophora cristata), narwhal (Monodon monoceros) and bowhead whale (Balaena mysticetus; Wiig et al. 1999; Laidre \& Heide-Jørgensen 201 1; Vacquie-Garcia, Lydersen, Biuw et al. 2017; Vacquie-Garcia, Lydersen, Marques et al. 2017). Lai et al. (2015) suggested that Arctic foxes can detect a resource hotspot, like marine carrion, on the sea ice as much as $40 \mathrm{~km}$ away. Sea-ice leads may offer a travelling fox a meal, but they may also constitute physical barriers several hundred metres wide, opening and refreezing over the course of a few days (Weeks 2010), which is another potential explanation for the stopovers. Alternatively, a blizzard or other adverse weather forced the fox to find shelter until conditions improved.

This female fox's journey offers an answer to Nansen's conjecture about the evidence he saw of Arctic foxes on the sea ice at $85^{\circ} \mathrm{N}$ : "Can they have gone astray?" he wondered (1897: 156). Arctic foxes observed far north on the ice-covered Arctic Ocean are likely engaged in longdistance dispersal rather than astray. Population genetic studies have shown that there is extensive gene flow among Arctic fox populations across all Arctic islands and continents that are connected with sea ice (Carmichael et al. 2007; Geffen et al. 2007; Norén et al. 2011). This is most likely the result of individuals dispersing between distant populations.

Norén et al. (2011) used population genetic analyses to infer that the immigration rate is higher than the emigration rate in Svalbard and that Arctic foxes in Svalbard immigrate from lemming-dominated ecosystems in North America and Siberia. This is in line with the suggestion that long-distance movements are more common among the lemming ecotype (low food availability after a lemming peak acting as a dispersal trigger) than in the coastal ecotype (Braestrup 1941; Pullainen 1965; Wrigley \& Hatch 1976; Roth 2002; Pamperin et al. 2008; Tarroux et al. 2010; Norén et al. 2011; Lai et al. 2015; Rioux et al. 2017). There is limited evidence to suggest that in some den areas in Svalbard some adult offspring may remain in their natal areas to help rear siblings (Norén et al. 2012). More research is required to confirm this. If it is the case, it would be a factor reducing the dispersal rate. The case of the female Arctic fox reported herein, as well as the emigration of an ear-tagged Arctic fox from Ny-Ålesund, Svalbard $\left(78^{\circ} 55^{\prime} \mathrm{N}, 11^{\circ} 56^{\prime} \mathrm{E}\right)$, that was shot some 1200 $\mathrm{km}$ away in the Russian archipelago of Novaya Zemlya
(Fuglei \& Øritsland 2003), suggests that although lower dispersal rates may be expected in the relatively more stable food webs experienced by coastal foxes in Svalbard, they still perform occasional long-distance dispersals that may be triggered by food shortages lasting for several weeks in winter (Prestrud 1992). However, we cannot make strong inferences about population-level emmigration rates based on one or two documented dispersal events. We must also keep in mind that long-distance natal dispersal can be expected to take place even in stable environments (Hamilton \& May 1977).

According to analyses of population genetics, circumpolar connectivity has been maintained among Arctic fox populations across most of the species' distribution range, likely because sea ice serves as a bridge linking distant populations. Consequently, there are very few isolated Arctic fox populations (Carmichael et al. 2007; Geffen et al. 2007; Norén et al. 2011). Rapid warming in the Arctic may change this (Gaston et al. 2012). In the waters around Svalbard, the general decline of sea-ice extent has already been reported to be affecting the spatial ecology of several species of sea mammals (Hamilton et al. 2015; Hamilton et al. 2017; Vacquie-Garcia et al. 2018). If Svalbard becomes ice-free throughout the year, it will imply an isolated Arctic fox population there, entirely cut off from other Arctic foxes, such fox populations may still be highly viable, as they are in Iceland (Hersteinsson $\delta$ Macdonald 1996) and the Beringian islands (Volodin et al. 2013), where isolated Arctic fox populations persist in a substantially warmer climate.

\section{Acknowledgements}

Methods used to trap and handle animals in our study were carried out in accordance with the principles and guidelines of the Norwegian Animal Welfare Act, with permission from the National Animal Research Authority of Norway. Permits for conducting the fieldwork were obtained from the Governor of Svalbard. We thank T. Sandal, E. Strømseng and A.M. Strømseng for participating in the fieldwork; C. Helgeland and M. Andersen for help with downloading, formatting and archiving the Argos tracking data; H.D. Jølle for assistance with the Nansen references; and R.A. Ims, G. Samelius and one anonymous reviewer for constructive comments on the manuscript.

\section{Funding}

The study was financially supported through the Climate-Ecological Observatory for Arctic Tundra project and by the Norwegian Polar Institute, including through the 
institute's Centre for Ice Climate and Ecosystems. AT was supported by the Norwegian Institute for Nature Research.

\section{Disclosure statement}

The authors report no conflict of interest.

\section{References}

Angerbjörn A., Hersteinsson P. \& Tannerfeldt M. 2004. Arctic foxes. Consequences of resource predictability in the Arctic fox-two life history strategies. In D.W. Macdonald \& C. Sillero-Zubiri (eds.): Biology and conservation of wild canids. Pp. 163-172. Oxford: Oxford University Press.

Assmy P., Fernández-Méndez M., Duarte P., Meyer A., Randelhoff A., Mundy C.J., Olsen L.M., Kauko H.M., Bailey A., Chierici M., Cohen L., Doulgeris A.P., Ehn J.K., Fransson A., Gerland S., Hop H., Hudson S.R., Hughes N., Itkin P., Johnsen G., King J.A., Koch B.P., Koenig Z., Kwasniewski S., Laney S.R., Nicolaus M., Pavlov A.K., Polashenski C.M., Provost C., Rösel A., Sandbu M., Spreen G., Smedsrud L.H., Sundfjord A., Taskjelle T., Tatarek A., Wiktor J., Wagner P.M., Wold A., Steen H. \& Granskog M.A. Leads in Arctic pack ice enable early phytoplankton blooms below snow-covered sea ice. Scientific Reports 7, article no. 40850, http://dx.doi.org/10.1038/ srep40850.

Bêty J., Gauthier G., Korpimäki E. \& Giroux J.-F. 2002. Shared predators and indirect trophic interactions: lemming cycles and Arctic-nesting geese. Journal of Animal Ecology 71, 88-98, http://dx.doi.org/10.1046/j.0021-8790.2001.00581.x.

Bivand R.S., Pebesma E.J. \& Gómez-Rubio V. 2008. Applied spatial data analysis with $R$. New York: Springer.

Braestrup F.W. 1941. A study of the Arctic fox in Greenland. Immigrations, fluctuations in numbers based mainly on trading statistics. Meddelelser om Gronland 131(4). Copenhagen: C.A. Reitzels, Commission for Scientific Investigations in Greenland.

Carmichael L.E., Krizan J., Nagy J.A., Fuglei E., Dumond M., Johnson D., Veitch A., Berteaux D. \& Strobeck C. 2007. Historical and ecological determinants of genetic structure in Arctic canids. Molecular Ecology 16, 3466-3483, http:// dx.doi.org/10.1111/j.1365-294X.2007.03381.x.

Chesemore D.L. 1968. Notes on the food habits of the Arctic foxes in northern Alaska. Canadian Journal of Zoology 46, 1127-1130, http://dx.doi.org/10.1139/z68-161

Clobert J., Danchin E., Dhondt A.A. \& Nichols J.D. 2001. Dispersal. New York: Oxford University Press.

CLS (Collecte Localisation Satellites) 2016. Argos user's manual. Largo, MD: CLS America.

Eberhardt L.E., Garrot R.A. \& Hanson W.C. 1983. Winter movements of Arctic foxes, Alopex lagopus, in a petroleum development area. Canadian Field-Naturalist 97, 66-70, http://dx.doi.org/10.2307/1380754

Eberhardt L.E. \& Hanson W.C. 1978. Long-distance movements of Arctic foxes tagged in northern Alaska. Canadian Field-Naturalist 92, 386-389.
Ehrich D., Ims R.A., Yoccoz N.G., Lecomte N., Killengreen S.T., Fuglei E., Rodnikova A.Y., Ebbinge B.S., Menyushina I.E., Nolet B.A., Pokrovsky I.G., Popov I.Y., Schmidt N.M., Sokolov A.A., Sokolova N.A. \& Sokolov V.A. 2015. What can stable isotope analysis of top predator tissues contribute to monitoring of tundra ecosystems? Ecosystems 18, 404-416, http://dx.doi.org/10.1007/s10021-014-9834-9.

Eide N.E., Jepsen J.U. \& Prestrud P. 2004. Spatial organization of reproductive Arctic foxes Alopex lagopus: responses to changes in spatial and temporal availability of prey. Journal of Animal Ecology 73, 1056-1068, http://dx.doi. org/10.1111/j.0021-8790.2004.00885.x.

Follmann E.H. \& Martin P. 2000. Feasibility of tracking Arctic foxes in northern Alaska using the Argos satellite system: preliminary results. Biotelemetry 15, 368-374.

Fuglei E. \& Ims R.A. 2008. Global warming and effects on the Arctic fox. Science Progress 91, 175-191, http://dx.doi.org/ $10.3184 / 003685008 \times 327468$

Fuglei E. \& Øritsland N.A. 2003. Energy cost of running in an Arctic fox (Alopex lagopus). Canadian Field-Naturalist 117 , 430-435, http://dx.doi.org/10.22621/cfn.v117i3.746.

Garrott R.A. \& Eberhardt L.E. 1987. Arctic fox. In M. Novak et al. (eds.): Wild furbearer management and conservation in North America. Pp. 394-406. Toronto: Ontario Ministry of Natural Resources.

Gaston A.J., Gavrilo M. \& Ebert C. 2012. Ice bridging as dispersal mechanism for Arctic terrestrial vertebrates and the possible consequences of reduced sea ice cover. Biodiversity 13, 182-190, http://dx.doi.org/10.1080/14888386.2012.7 19177.

GEBCO 2019. General Bathymetric Chart of the Oceans. Accessed on the internet at https://www.gebco.net on 16 April 2019.

Geffen E., Waidyaratne S., Dalén L., Angerbjörn A., Vila C., Hersteinsson P., Fuglei E., White P.A., Goltsman M. \& Wayne R.K. 2007. Sea ice occurrence predicts genetic isolation in the Arctic fox. Molecular Ecology 16, 4241-4255, http://dx.doi.org/10.1111/j.1365-294X.2007.03507.x.

Hamilton C., Kovacs K., Ims R.A., Aars J. \& Lydersen C. 2017. An Arctic predator-prey system in flux: climate change impacts on coastal space use by polar bears and ringed seals. Journal of Animal Ecology 86, 1054-1064, http://dx.doi.org/10.1111/1365-2656.12685.

Hamilton C., Lydersen C., Ims R.A. \& Kovacs K. 2015. Predictions replaced by facts: a keystone species' behavioural responses to declining Arctic sea-ice. Biology Letters 11, article no. 20150803, http://dx.doi.org/10.1098/rsbl. 2015.0803.

Hamilton W.D. \& May R.M. 1977. Dispersal instable habitats. Nature 269, 578-581, http://dx.doi.org/10.1038/269578a0.

Hersteinsson P. \& Macdonald D.W. 1996. Diet of Arctic foxes (Alopex lagopus) in Iceland. Journal of Zoology 240, 457-474, http://dx.doi.org/10.1111/j.1469-7998.1996.tb05298.x.

Hijmans R.J. 2018. Raster: geographic data analysis and modeling. $\mathrm{R}$ package version 2.8.4. Accessed on the internet at https://CRAN.R-project.org/package=raster.

Ims R.A. \& Hjermann D.Ø. 2001. Condition dependent dispersal. In J. Clobert et al. (eds.): Dispersal. Pp. 203-216. Oxford: Oxford University Press. 
Jonsen I. 2016. Joint estimation over multiple individuals improves behavioural state inference from animal movement data. Scientific Reports 6, article no. 20625, http://dx. doi.org/10.1038/srep20625.

Jonsen I.D., Mills Flemming J. \& Myers R.A. 2005. Robust state-space modeling of animal movement data. Ecology 86 , 2874-2880, http://dx.doi.org/10.1890/04-1852

Lai S., Bêty J. \& Berteaux D. 2015. Spatio-temporal hotspots of satellite-tracked Arctic foxes reveal a large detection range in a mammalian predator. Movement Ecology 3, article no. 37, http://dx.doi.org/10.1186/s40462-015-0065-2.

Lai S., Bêty J. \& Berteaux D. 2017. Movement tactics of a mobile predator in a meta-ecosystem with fluctuation resources: the Arctic fox in the High Arctic. Oikos 126, 937-947, http://dx.doi.org/10.1111/oik.03948.

Laidre K.L. \& Heide-Jørgensen M.P. 2011. Life in the lead: extreme densities of narwhals Monodon monoceros in the offshore pack ice. Marine Ecology Progress Series 423, 269-278, http://dx.doi.org/10.3354/meps08941.

Lehner N.S. 2012. Arctic fox winter movement and diet in relation to industrial development on Alaska's North slope. Master of Science thesis, Faculty of the University of Alaska Fairbanks, Fairbanks, AK.

Lydersen C. \& Gjertz I. 1986. Studies of the ringed seal (Phoca hispida Schreber 1775) in its breeding habitat in Kongsfjorden, Svalbard. Polar Research 4, 57-63, http://dx.doi. org/10.3402/polar.v4il.6920.

Nansen F. 1897. Farthest north. London: Gibson Square Books.

Norén K., Carmichael L., Fuglei E., Eide N.E., Hersteinsson P. \& Angerbjörn A. 2011 . Pulses of movement across the sea ice: population connectivity and temporal genetic structure in the Arctic fox. Oecologia 166, 973-984, http://dx. doi.org/10.1007/s00442-011-1939-7.

Norén K., Hersteinsson P., Samelius G., Eide N.E., Fuglei E., Elmhagen B., Dalén L., Meijer T. \& Angerbjörn A. 2012. From monogamy to complexity: Arctic fox social organization in contrasting ecosystems. Canadian Journal Zoology 90, 1102-1116, http://dx.doi.org/10.1139/Z2012-077.

Nybakk K., Kjørstad M., Overskaug K., Kvam T. \& Linnell J.D.C., Andersen R., Berntsen F. 1996. Experiences with live-capture and radio collaring of lynx (Lynx lynx) in Norway. Fauna Norvegica Series A 17, 17-26.

Pamperin N.J., Follmann E.H. \& Petersen B. 2008. Sea-ice use by Arctic foxes in northern Alaska. Polar Biology 31, 1421-1426, http://dx.doi.org/10.1007/s00300-008-0481-5.

Prestrud P. 1992. Food habits and observations of the hunting behaviour of Arctic foxes, Alopex lagopus, in Svalbard. Canadian Field-Naturalist 106, 225-236.

Pullainen E. 1965. On the distribution and migrations of the Arctic fox (Alopex lagopus L.) in Finland. Aquilo Serie Zoologica 2, 25-26.
R Development Core Team 2018. R: a language and environment for statistical computing. Vienna: R Foundation for Statistical Computing.

Rioux M.-J., Lai S., Casajus N., Bêty J. \& Berteaux D. 2017. Winter home range fidelity and extraterritorial movements of Arctic fox pairs in the Canadian High Arctic. Polar Research 36 Suppl. 1, article no. 11, http://dx.doi.org/10.10 80/17518369.2017.1316930.

Roth J.D. 2002. Temporal variability in Arctic fox diet as reflected in stable-carbon isotopes; the importance of sea ice. Oecologia 133, 70-77, http://dx.doi.org/10.1007/ s00442-002-1004-7.

Smith T.G. 1980. Polar bear predation of ringed and bearded seals in the land-fast sea ice habitat. Canadian Journal of Zoology 58, 2201-2209, http://dx.doi.org/10.1139/z80-302

Spreen G., Kaleschke L. \& Heygster G. 2008. Sea ice remote sensing using AMSR-E 89-GHz channels. Journal of Geophysical Research-Oceans 113, C02S03, http://dx.doi. org/10.1029/2005JC003384.

Tarroux A., Berteaux D. \& Bêty J. 2010. Northern nomads: ability for extensive movements in adult Arctic foxes. Polar Biology 33, 1021-1026, http://dx.doi.org/10.1007/ s00300-010-0780-5.

Vacquie-Garcia J., Lydersen C., Biuw M., Haug T., Fedak M.A. \& Kovacs K. 2017. Hooded seal Cystophora cristata foraging areas in the northeast Atlantic Ocean-investigated using three complementary methods. PLoS One 12, e0187889, http://doi.org/10.1371/journal.pone.0187889.

Vacquie-Garcia J., Lydersen C., Ims R.A. \& Kovacs K. 2018. Habitats and movement patterns of white whales Delphinapterus leucas in Svalbard, Norway in a changing climate. Movement Ecology 6, article no. 21, http://dx.doi. org/10.1186/s40462-018-0139-z.

Vacquie-Garcia J., Lydersen C., Marques T.A., Aars J., Ahonen H., Skern-Mauritzen M., Oien N. \& Kovacs K. 2017. Late summer distribution and abundance of ice-associated whales in the Norwegian High Arctic. Endangered Species Research 32, 59-70, http://dx.doi.org/10.3354/esr00791.

Volodin A.A., Kalashnikova M.V., Klinkova E.S., Goltsman A.M., Goltsman M.E. \& Kruchenkova E.P. 2013. Structure of Arctic fox (Alopex lagopus beringensis) colonies in the northern extremity of Bering Island. Biology Bulletin 40, 614-625, http://dx.doi.org/10.1134/S106235901307008X.

Weeks W. 2010. On sea ice. Fairbanks: University of Alaska Press.

Wiig O., Derocher A.E. \& Belikov S.E. 1999. Ringed seal (Phoca hispida) breeding in the drifting pack ice of the Barents Sea. Marine Mammal Science 15, 595-598, http://dx. doi.org/10.1111/j.1748-7692.1999.tb00828.x.

Wrigley R.E. \& Hatch D.R.M. 1976. Arctic fox migrations in Manitoba. Arctic 29, 147-157, http://dx.doi.org/10.14430/ $\operatorname{arctic} 2798$ 